\title{
Effect of piospheres on physio-chemical soil properties in the Southern Rangelands of Kenya
}

\author{
S. O. Jawuoro ${ }^{*}$, O. K. Koech, G. N. Karuku and J. S. Mbau
}

\begin{abstract}
Introduction: Water-based interventions haphazardly introduced in the drylands of Kenya have led to the introduction of piospheres used as concentration mounts. Not much is known about the effect of these piospheres on soil physio-chemical properties, especially in the Kenyan rangelands where the government and other development agencies have created piospheres aimed at curbing water shortages and sustaining livestock production. The study assessed the effect of piospheres on soil physio-chemical characteristics in the southern rangelands of Kajiado, Kenya, in order to provide evidence-based insights that will be useful in guiding future water interventions.

Methods: Soil samples were collected within $0.25-\mathrm{m}^{2}$ plots at 20-m intervals along 100-m transects from three piospheres (a dam, a trough, and a seasonal river). Two-way ANOVA was used to determine if there were significant differences in soil parameters between piospheric distances.

Results: Soil bulk density significantly different between piospheric distances $(F=22.25, P=0.001)$ and piospheres $(F=13.10, P=0.002)$, being highest at $20 \mathrm{~m}$ from the trough $\left(1.1-1.21 \mathrm{gcm}^{-3}\right)$ relative to a similar distance from the dam $\left(1.01-1.20 \mathrm{gcm}^{-3}\right)$ and the river $\left(1.1-1.17 \mathrm{gcm}^{-3}\right)$. On the other hand, mean soil aggregate stability significantly increased $(F=66.89, P=0.001)$ with piospheric distance, being lowest at $20 \mathrm{~m}$ from the trough $(43.9-46.2 \%)$, the dam (43.1-48.9\%), and the river (46.6-47.5\%).

Conclusions: High soil bulk density and consequent low soil porosity, hydraulic conductivity, and moisture content demonstrated that grazing was high near the piospheres. It is recommended that livestock should be herded away from the piospheres after drinking water to ensure that grazing livestock spend less time near the piospheres if reduced soil compaction is to be realized. Piospheres should also be better planned and placed at landscape level to exploit landscape heterogeneity.
\end{abstract}

Keywords: Piospheres, Grazing pressure, Bulk density, Hydraulic conductivity, Rangelands

\section{Introduction}

Piospheres create an attenuating pattern form of grazing as a result of concentrated activity around them thereby developing a unique source of analysis of range trend and condition distinct from other environmental factors (Brooks and Matchett 2006; Todd 2006). Several studies have revealed that piospheres, created to curb water scarcity in most rangelands across the world, have adverse effects on both soil and vegetation (Brooks and Matchett 2006; Landman et al. 2012; Shahriary et al. 2012).

\footnotetext{
* Correspondence: stanleyjawuoro@gmail.com

Department of Land Resource Management and Agricultural Technology (LARMAT), University of Nairobi, P.O. Box 29053-00625, Nairobi, Kenya
}

Concentrated grazing around these piospheres leads to excessive trampling which causes soil compaction, increasing soil bulk density and reducing soil porosity in the process (Gomez et al. 2006; Stankovičová et al. 2008). Reduced soil pore volume impedes percolation of water through the soil hence low soil moisture levels (Chaichi et al. 2005). Compacted soils hamper air and water circulation, hinder root penetration into the soil, and limit seed germination and seedling establishment in the rangelands (Amiri et al. 2008; Azarnivand et al. 2010). Grazing animals also alter soil nutrient and chemical composition through deposition resulting from urination and defecation (Shahriary et al. 2012). Dung deposition has 
been known to influence soil organic carbon and total nitrogen concentrations (Han et al. 2008; Ingram et al. 2008 ) in addition to altering soil $\mathrm{pH}$ and soil microbial activity (Bell 2010; Alaoui et al. 2011).

Research has not conclusively established the effect of piospheres on physical and chemical properties of the soil. Therefore, there is need for conclusive insights on the piospheric effect on soil physio-chemical characteristics because such information is useful in developing sustainable water interventions for improved water availability in the rangelands. These findings will particularly be relevant in Kenyan rangelands where there is widespread introduction of piospheres to alleviate water scarcity (Wahome et al. 2014). Research on piospheric effect on soils has been done in parts of East Africa and Asia (Shahriary et al. 2012; Anthony et al. 2015). A study conducted by Anthony et al. (2015) in the Karamoja subregion of Uganda showed low levels of nitrogen near the piospheres. On the contrary, Shahriary et al. (2012) reported a high concentration of nitrogen near the piospheres of Iran. The disparity observed in these findings could be because of the varying residence time spent by grazing animal around the piospheres as a result of, among other factors, different grazing regimes (Sternberg 2012), differences in piosphere types and location which determine the patterns of landscape use by grazing animals (Anthony et al. 2015) and differential response of various soil types upon exposure to grazing (Sun et al. 2011; Schrama et al. 2013). This study therefore sought to assess the effect of piospheres on soil physical and chemical characteristics in the Southern rangelands of Kenya and their predisposing factors.

\section{Methods}

\section{Study area}

The study was done in Kiserian, Kajiado County, Kenya. The County is located between $36^{\circ} 5$ ' and $37^{\circ} 5$ ' East and $1^{\circ}$ and $3^{\circ}$ South (Fig. 1). The altitude ranges from 1580 to 2460 masl. Kiserian is found in agro-ecological zone IV and is therefore a semi-arid region. Rainfall is generally low, bimodal and highly varying across the county. The average annual rainfall ranges between 327 and 1576 mm.yr. The short rains are received during November-December $(30.97 \pm 27.85 \%$ of the annual total) whereas the long rains fall from March to May $(47.5 \pm 15.06 \%$ of the annual total). The dry season spans from June to September. Droughts are long and frequent, and are majorly associated with failure of the short rains. Temperatures range between $12^{\circ} \mathrm{C}$ and $34^{\circ}$ $\mathrm{C}$, are coolest from July to August and hottest from November to April. Both the minimum (by $1.81 \pm 0.46{ }^{\circ} \mathrm{C}$ between 1961 and 2013) and maximum $\left(0.275^{\circ} \mathrm{C}\right.$ annual difference between 1976 and 2001) temperatures are rising in the county (Ogutu et al. 2013). The ratio of

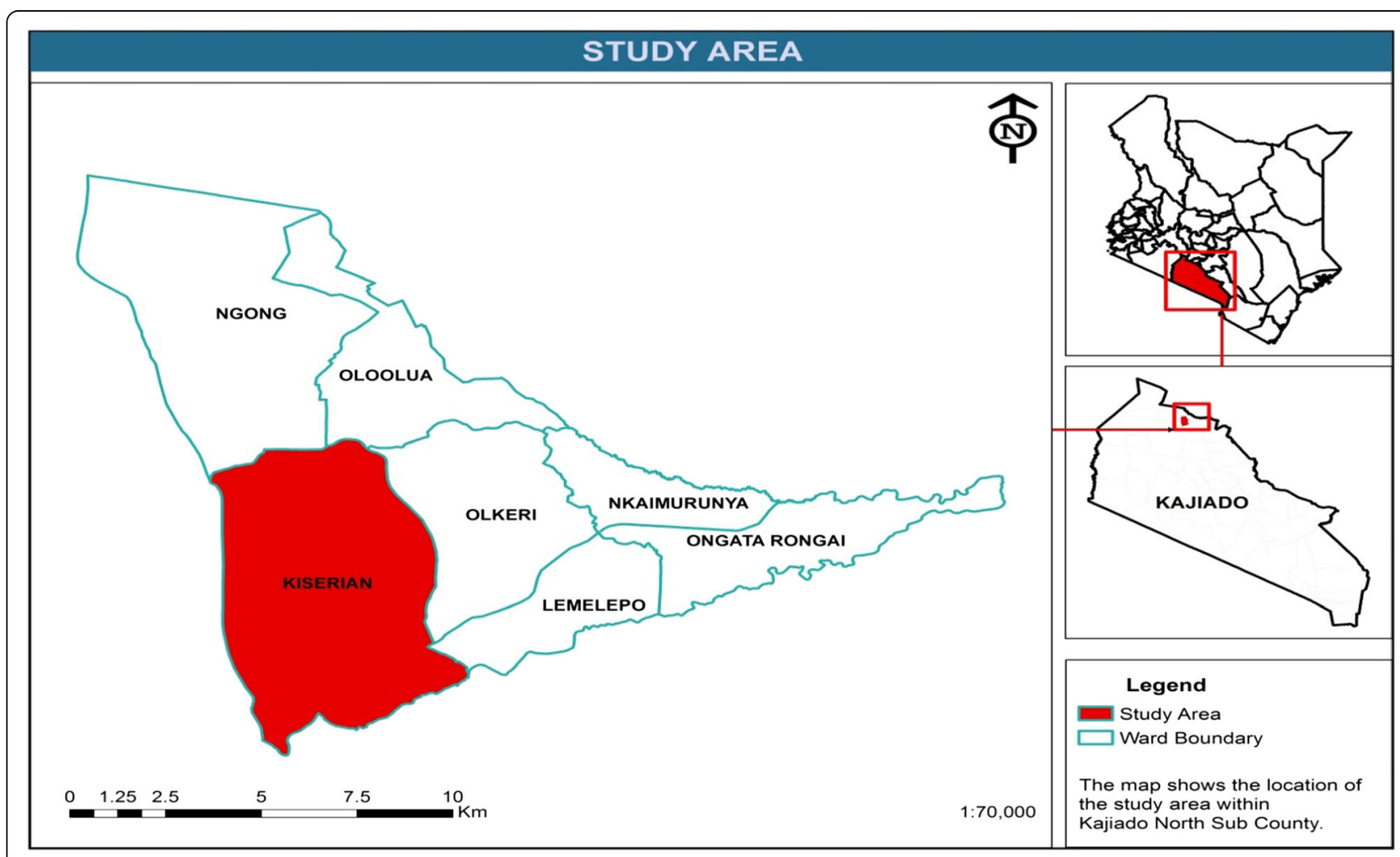

Fig. 1 Map of the study area 
rainfall to evapotranspiration is $<0.65$ (Middleton and Thomas 1997). The main soil type in Kiserian is vertisol which is sticky when wet and forms large cracks when dry (Ombogo 2013). Acacia mellifera, Acacia tortilis, Acacia nubica, Acacia ancistroclada, Acacia nilotica, Commiphora riparia, Commiphora africana, and Balanites aegyptiaca are the most common species (Bekure 1991).

\section{Research design}

A randomized block design was used for this research with four watering points forming blocks while plots (5) were the distances (treatments) from water points. Quadrats $(0.5 \mathrm{~m}$ by $0.5 \mathrm{~m})$ were the main sampling points, placed at intervals of $20 \mathrm{~m}, 40,60,80$, and $100 \mathrm{~m}$ within a $100-\mathrm{m}$ transect from the watering point. Each treatment was replicated four times in the East, West, North, and South directions from the watering points. Two troughs, a dam and a river, were selected for study. The troughs were smaller in size compared to the dam and could have an impact by increasing grazing pressure around it due to greater animal concentration. The dam was large in size and thus could reduce grazing impact around it because of its large surface area that enabled animals even distribution. The river, being a natural water source, was used as a control, providing the basis for comparison between introduced systems and natural systems.

\section{Soil sampling and laboratory analysis}

Both disturbed and undisturbed soil samples were collected for analysis. Disturbed soil samples were collected using a $600 \mathrm{~cm}^{3}$ soil auger at a depth of $20 \mathrm{~cm}$. Four samples were taken from the corners and centre of each quadrat and then mixed in a bucket to form a composite sample for each replication. These composites were divided into four segments where one segment was picked to form a representative sub-sample of $125 \mathrm{~g}$. This procedure was repeated for all replications until a representative sample of $500 \mathrm{~g}$ was obtained. These representative samples were air-dried at room temperature for $72 \mathrm{~h}$, ground and sieved through $2 \mathrm{~mm}$ mesh to remove plant roots, stones and organic residues. These samples were used for texture and $\mathrm{pH}$ determination. For texture and $\mathrm{pH}$ determination a $2 \mathrm{~mm}$ sieve was used because soil samples $>2 \mathrm{~g}$ were required for analysis. Further sieving was done using a $0.5-\mathrm{mm}$ sieve. This was to enhance soil sample homogeneity since $<2 \mathrm{~g}$ of the soil sample was required for analysis (Brenner and Mulvaney 1982; Buresh et al. 1982). The samples obtained were used for organic carbon and total nitrogen determination. Undisturbed soil samples were obtained at the same depth using steel core rings for bulk density, porosity and saturated hydraulic conductivity determination.
Soil organic carbon concentration was determined using Walkley-Black wet oxidation method as described by Nelson and Sommers (1982), while total nitrogen was determined using Kjeldahl digestion method (Brenner and Mulvaney 1982). Bulk density was estimated using the core method after oven drying the soil at $105^{\circ} \mathrm{c}$ for $48 \mathrm{~h}$ (McKenzie et al. 2004), and was calculated by dividing the mass of dry weight of soil (g) by the soil volume $\left(\mathrm{cm}^{3}\right)$. From the bulk density values obtained, porosity, $f$, was calculated in accordance with Flint and Flint (2002) using the formula $1-\frac{\rho_{b}}{\rho_{S}}$ where, $\rho_{\mathrm{b}}$ is bulk density and $\rho_{\mathrm{s}}$ the particle density taken as $2.65 \mathrm{~g} \mathrm{~cm}^{-3}$. Particle size distribution was analyzed using the hydrometer method after dispersing soil and eliminating organic matter (Day 1965), and $\mathrm{pH}-\mathrm{H}_{2} \mathrm{O}$ (ratio 1:2.5) by a $\mathrm{pH}$ meter (Mclean 1982). Aggregate stability was determined by the wet sieving method while soil moisture content was determined by gravimetric method. Saturated soil hydraulic conductivity was determined by the constant head permeameter described by Reynolds and Elrick (2002) based on application of Darcy equation. A hydraulic head difference was imposed on the soil column and the resulting flux of water measured.

$$
\text { Conductivity }=\frac{V \cdot L}{A \cdot T \cdot H}
$$

, where $V=$ volume of water $(Q)$ that flows through the sample of cross sectional area $(A)$ in time $T$ and $H$ is the hydraulic head difference imposed across a sample length $(L)$.

\section{Statistical analysis}

Statistical analyses for soil parameters were performed using GenStat $15^{\text {th }}$ edition. Two-way ANOVA was used to determine if there were significant differences between means of various treatments and seasons. Tukey's HSD test was used to compare the means. Significance was obtained at $P \leq 0.05$.

\section{Results and discussion}

\section{Soil bulk density}

Table 1 shows soil bulk density, porosity, saturated hydraulic conductivity, aggregate stability, and soil moisture content at various distances from the dam, the trough, and the seasonal river. Soil bulk density significantly decreased $(F=25.07, P=0.001)$ with piospheric distance and was significantly different $(F=13.10, P=$ 0.002 ) between piospheres. Troughs were smaller in size compared to the dam. Therefore, the surface area available for grazing animals was reduced leading to greater compaction. Due to the fact that the main soil type was vertisols, bulk density was significantly different between seasons $(F=5.92, P=0.035)$, being higher during the wet 
Table 1 Soil physical properties at various piospheric distances (in meters)

\begin{tabular}{|c|c|c|c|c|c|c|c|c|c|c|c|}
\hline \multirow[b]{2}{*}{ Piosphere } & \multicolumn{6}{|l|}{ Wet season } & \multicolumn{5}{|l|}{ Dry season } \\
\hline & Distance $(\mathrm{m})$ & $\mathrm{BD}\left(\mathrm{gcm}^{-3}\right)$ & \%Porosity & K-Sat & $\%$ SA & $\% M C$ & $\mathrm{BD}\left(\mathrm{gcm}^{3}\right)$ & Porosity & K-sat & SA & $\% \mathrm{MC}$ \\
\hline \multirow[t]{5}{*}{ Dam } & 20 & $1.20 \mathrm{~b}$ & $55.84 a$ & $0.04 a$ & $43.05 a$ & 20.90a & $1.09 \mathrm{c}$ & $58.86 a$ & $0.05 a$ & 48.86a & 18.90a \\
\hline & 40 & 1.07ab & 59.24ab & $0.07 a$ & 46.52ab & 25.40ab & $1.06 \mathrm{bc}$ & $60.00 \mathrm{ab}$ & $0.07 a$ & $50.00 a$ & $21.10 a$ \\
\hline & 60 & $1.05 a b$ & $60.00 \mathrm{~b}$ & $0.13 b$ & $50.30 \mathrm{bc}$ & $25.80 \mathrm{~b}$ & $1.06 a b$ & $60.00 \mathrm{ab}$ & $0.11 \mathrm{ab}$ & $46.17 a$ & 19.60a \\
\hline & 80 & $1.02 \mathrm{a}$ & $60.37 b c$ & $0.13 b$ & $50.81 \mathrm{c}$ & $26.20 \mathrm{bc}$ & $1.05 a b$ & $60.37 b$ & $0.12 b$ & $50.37 a$ & 20.40a \\
\hline & 100 & $1.01 \mathrm{a}$ & $61.13 c$ & $0.33 c$ & $51.80 d$ & $30.70 c$ & $1.03 a$ & $61.13 c$ & $0.29 c$ & $51.13 a$ & $20.60 a$ \\
\hline \multirow[t]{5}{*}{ Trough } & 20 & $1.23 \mathrm{c}$ & $53.66 a$ & $0.11 a$ & $43.92 a$ & $18.40 a$ & $1.19 c$ & $56.23 a$ & $0.11 a$ & $46.23 a$ & 11.60a \\
\hline & 40 & $1.19 b c$ & 55.09ab & $0.13 a$ & $44.53 a$ & 21.90ab & $1.16 \mathrm{bc}$ & 56.43ab & $0.12 \mathrm{a}$ & $46.42 \mathrm{a}$ & 11.90a \\
\hline & 60 & $1.16 a b$ & $56.41 b$ & $0.19 b$ & $50.31 b$ & $24.20 \mathrm{~b}$ & $1.14 \mathrm{bc}$ & $57.17 b$ & $0.20 \mathrm{a}$ & 47.17ab & 12.60ab \\
\hline & 80 & 1.09ab & $58.87 \mathrm{bc}$ & $0.94 c$ & $50.31 b$ & $26.10 b c$ & $1.11 \mathrm{~b}$ & $58.11 b c$ & $0.89 b$ & $48.11 \mathrm{ab}$ & 12.80ab \\
\hline & 100 & $1.07 a$ & $59.81 \mathrm{C}$ & $5.15 d$ & $56.98 c$ & $31.80 \mathrm{c}$ & $0.96 a$ & $63.96 c$ & $4.68 c$ & $53.96 b$ & $16.50 \mathrm{~b}$ \\
\hline \multirow[t]{6}{*}{ River } & 20 & $1.17 \mathrm{c}$ & $54.72 a$ & $0.03 a$ & $47.54 a$ & $20.10 a$ & $1.2 d$ & $56.61 a$ & $0.02 a$ & $46.61 a$ & 11.50a \\
\hline & 40 & $1.08 a b$ & 59.62ab & $0.11 \mathrm{ab}$ & 48.89ab & $21.20 a$ & $1.07 \mathrm{C}$ & $59.64 b$ & $0.11 a$ & $49.64 b$ & 11.60a \\
\hline & 60 & $1.06 \mathrm{~b}$ & $60.37 b$ & $0.39 b$ & $49.25 b c$ & 22.60ab & $1.02 \mathrm{~b}$ & $61.52 \mathrm{bc}$ & $0.37 a$ & $51.52 \mathrm{bc}$ & 11.90a \\
\hline & 80 & $1.05 b$ & $61.51 b c$ & $4.64 c$ & $50.87 c$ & $23.10 b$ & $1.01 \mathrm{~b}$ & $61.89 \mathrm{bc}$ & $4.68 b$ & $51.89 \mathrm{bc}$ & 12.60ab \\
\hline & 100 & $1.00 \mathrm{a}$ & $61.89 c$ & $5.81 d$ & $55.85 d$ & $25.10 c$ & $0.89 a$ & $66.41 c$ & $5.92 \mathrm{C}$ & $56.41 c$ & $13.70 b$ \\
\hline & LSD & 0.05 & 2.04 & 3.17 & 3.74 & 5.54 & 0.82 & 2.93 & 2.17 & 3.87 & 6.95 \\
\hline
\end{tabular}

Means with the same letters within a column are not significantly different $(P \leq 0.05)$

Key: $\mathrm{BD}=$ Soil bulk density; $\mathrm{K}$-sat = saturated hydraulic conductivity; $\% \mathrm{SA}=$ Soil aggregate stability; \%MC = Soil moisture content

season as a result of greater compaction. During the dry, season vertisols become hard and crack, making it difficult to compact even under heavy grazing. The interactions between treatments (distance $\times$ season $\times$ piosphere) were, however, not significant $(F=0.52, P=0.818)$.

The results demonstrate greater compaction around zones of high intensity grazing. Arnhold et al. (2015) observed increased soil bulk densities in areas where high intensity grazing was applied in the Lambwe Valley of Kenya. Similarly, Shahriary et al. (2012) and Anthony et al. (2015) reported increased trampling and soil compaction around the piospheres of Iran and Uganda, respectively. The findings of this study also corroborate with those of Smet and Ward (2006) who reported high soil compaction levels around South African piospheres.

\section{Saturated hydraulic conductivity and soil moisture content}

Saturated hydraulic conductivity significantly increased ( $F=1084.51, P<0.001)$ with piospheric distance, being higher away from the piospheres. This could be attributed to high compaction levels that reduced soil porosity inhibiting percolation of water into the soil, further exacerbated by high animal trampling which reduced plant cover and exposed the soil to solar radiation triggering moisture loss through evaporation. No significant difference was observed in saturated hydraulic conductivity between the piospheres $(F=2.53, P=0.294)$ and seasons $(F=1.07, P=0.326)$. The interactions between treatments (distance $\times$ season $\times$ piosphere) were also not significant $(F=0.60, P=0.762)$. Due to the low infiltration near the piospheres, soil moisture content was significantly lower ( $F=16.94, P<0.001)$ near the piospheres. No significant difference $(F=0.26, P=0.618)$ was observed in soil moisture content between piospheres. Higher rainfall during the wet season increased moisture input into the soil as compared to the dry season. Consequently, soil moisture content was significantly higher $(F=256.76, \quad P<0.001)$ during the wet season. The interactions between treatments were not significant $(F=1.57, P=0.247)$.

These findings corroborate with those of Zhang et al. (2006) and Azarnivand et al. (2010) that high soil compaction reduced water infiltration in the loess soils of China and the rangelands of Hosainabad, respectively. Amiri et al. (2008) also observed higher soil moisture content in light and moderately grazed lands compared to areas under heavy grazing intensity in the rangelands of Isfahan.

\section{Soil aggregate stability}

Soil aggregate stability significantly increased $(F=66.89$, $P<0.001)$ with piospheric distance, though there was no significant difference $(F=3.43, P=0.073)$ between piospheres. Because the soil class type was mainly sandy clay loam, soil was highly disintegrated during the wet season when sticky as opposed to dry season when it cracked. The aggregate stability of the soils was thus therefore significantly lower during the wet season $(F=698.41, P<0.001)$. 
The interactions between treatments (distance $\times$ season $\times$ piosphere) were not significant $(F=1.55, P=0.254)$.

Heavy grazing reduces soil aggregate stability due to high compaction. Animal trampling reduces plant cover thereby exposing the soil to direct raindrops which disintegrate soil particles (Wasonga 2009; Mugerwa and Emmanuel 2014). This could be the probable reason for the low aggregate stability observed near the piospheres. Alphayo (2015) also observed low soil aggregate stability under high intensity grazing in Laikipia County, Kenya. Similarly, Azarnivand et al. (2010) and Cournane et al. (2010) reported low soil aggregate stability under heavy grazing compared Hosainabad and Otago rangelands, respectively.

\section{Soil textural characteristics}

Table 2 shows soil textural characteristics, soil organic carbon, total nitrogen, and $\mathrm{pH}$ at various distances from the dam, the trough, and the river. The soil textural class was sandy clay loam across all the piospheres. Sand content was higher near the piospheres although the difference between piospheric distances was not significant $(F=2.73, \quad P=0.090)$. Besides, the difference in sand content was not significantly different between piospheres $(F=1.79, P=0.217)$ and seasons $(F=0.86, P=0.574)$. The interactions between treatments (distance $\times$ season $\times$ piosphere) were also not significant $(F=0.01, P=1.000)$.

Clay content significantly increased $(F=14.43, P<$ 0.001 ) with distance from the piospheres. The difference observed in clay content was however neither significant between piospheres $(F=0.38, P=0.557)$ nor seasons $(F=0.01, P=1.000)$. The interactions between the various treatments (distance $\times$ season $\times$ piosphere) were also not significant $(F=0.01, P=1.000)$.

The high sand content near the piospheres could be attributed to increased degradation around the piospheres that exposed the soil to erosion. Fine particles of clay and silt were thus carried off by either wind or water erosion, justifying the significantly higher clay content observed away from these piospheres. Similar observations were made by Al-Seekh et al. (2009) who reported higher percentage of sand in grazed areas compared to un-grazed and mildly grazed sites in the rangelands of Hebron in Palestine. Pei et al. (2008) also observed higher sand content in degraded rangelands relative to enclosures of Palestine. In addition, Mohammed (2000) reported that overgrazing in the southern West Bank resulted in severe soil erosion that caused the soil to lose its silt and clay and increase sand content.

\section{Soil organic carbon and total nitrogen}

A significantly higher $(F=17.24, P<0.001)$ soil organic carbon was recorded near the piospheres, being highest at a piospheric distance of $20 \mathrm{~m}$. There was, however, no significant difference in soil organic carbon between piospheres $(F=0.77, P=0.489)$ and seasons $(F=0.95, P=0.520)$. Moreover, the interactions

Table 2 Soil textural properties, organic carbon, nitrogen and $\mathrm{pH}$ at various piospheric distances

\begin{tabular}{|c|c|c|c|c|c|c|c|c|c|c|c|c|c|}
\hline \multirow[b]{2}{*}{ Piosphere } & \multicolumn{7}{|l|}{ Wet Season } & \multicolumn{6}{|c|}{ Dry season } \\
\hline & Distance $(\mathrm{m})$ & \% Sand & $\%$ Clay & $\%$ Silt & $\% O C$ & $\% N$ & $\mathrm{pH}$ & \%Sand & $\%$ Clay & $\%$ Silt & $\% O C$ & $\% N$ & $\mathrm{pH}$ \\
\hline \multirow[t]{5}{*}{ Dam } & 20 & $65.40 c$ & $28.50 a$ & $6.10 a$ & $2.92 d$ & $0.35 b$ & $6.46 b$ & $64.60 c$ & $28.62 a$ & $6.78 a$ & $3.01 d$ & $0.36 b$ & $6.42 b$ \\
\hline & 40 & $62.80 \mathrm{~b}$ & 32.50ab & $4.70 a$ & $2.74 \mathrm{~cd}$ & $0.33 a b$ & $6.03 b$ & $62.84 \mathrm{bc}$ & $32.57 a b$ & $4.59 a$ & $2.69 \mathrm{~cd}$ & $0.31 \mathrm{ab}$ & $6.04 b$ \\
\hline & 60 & $62.60 \mathrm{~b}$ & $34.50 \mathrm{bc}$ & $2.90 a$ & $2.58 \mathrm{bc}$ & $0.24 a b$ & $5.85 a b$ & $62.71 b c$ & $34.29 b c$ & $3.01 a$ & $2.54 \mathrm{~cd}$ & $0.21 a$ & $5.88 \mathrm{ab}$ \\
\hline & 80 & $62.60 \mathrm{~b}$ & $34.50 \mathrm{bc}$ & $2.90 a$ & $2.56 a b$ & $0.14 a b$ & $5.85 a b$ & $61.90 \mathrm{~b}$ & $34.51 b c$ & $3.59 a$ & $2.59 \mathrm{bc}$ & $0.21 a$ & $5.72 \mathrm{a}$ \\
\hline & 100 & $55.80 a$ & $36.50 c$ & 7.70a & $2.43 a$ & $0.09 a$ & $5.75 a$ & $55.80 a$ & $36.50 c$ & $7.71 a$ & 2.33ab & $0.21 a$ & $5.66 a$ \\
\hline \multirow[t]{5}{*}{ Trough } & 20 & $61.50 \mathrm{~b}$ & $29.50 a$ & $9.01 a$ & $3.21 \mathrm{~d}$ & $0.43 c$ & $6.32 b$ & $61.50 \mathrm{~b}$ & $32.50 a$ & $6.01 a$ & $3.14 d$ & $0.37 b$ & $6.43 b$ \\
\hline & 40 & $60.40 \mathrm{~b}$ & 31.60ab & $8.02 a$ & $3.21 d$ & $0.26 b$ & $6.07 a b$ & $61.21 b$ & $34.60 a b$ & $4.19 a$ & $3.07 \mathrm{~cd}$ & $0.33 a b$ & $6.08 \mathrm{~b}$ \\
\hline & 60 & $58.70 a b$ & $34.30 \mathrm{bc}$ & $7.01 a$ & $3.15 \mathrm{~cd}$ & $0.23 a b$ & $5.92 \mathrm{ab}$ & $58.75 a b$ & $35.32 \mathrm{bc}$ & $5.93 a$ & $2.96 \mathrm{bc}$ & $0.25 a b$ & $5.94 a b$ \\
\hline & 80 & 57.64ab & $35.20 b c$ & $7.16 a$ & $2.98 \mathrm{ab}$ & $0.22 a b$ & $5.88 \mathrm{ab}$ & 57.37ab & $38.50 \mathrm{bc}$ & $4.13 a$ & 2.89ab & $0.20 \mathrm{a}$ & $5.89 a$ \\
\hline & 100 & $55.82 a$ & $36.90 c$ & $7.28 a$ & $2.92 a$ & $0.19 a$ & $5.71 a$ & $55.72 a$ & $40.50 c$ & $3.67 a$ & $2.85 a$ & $0.18 a$ & $5.76 a$ \\
\hline \multirow[t]{6}{*}{ River } & 20 & $64.92 c$ & $28.60 a$ & $9.80 a$ & $3.42 c$ & $0.23 a b$ & $6.37 b$ & $64.92 c$ & $26.50 a$ & $8.58 a$ & $3.24 d$ & $0.25 b$ & $6.26 c$ \\
\hline & 40 & $63.21 c$ & $29.50 a$ & $7.19 a$ & $3.02 \mathrm{bc}$ & $0.23 a b$ & $6.05 b$ & $61.21 b c$ & $29.50 a b$ & $9.28 a$ & $2.91 \mathrm{~cd}$ & $0.24 b$ & $6.03 b$ \\
\hline & 60 & $60.30 \mathrm{bc}$ & $32.10 \mathrm{~b}$ & $9.29 a$ & $2.92 \mathrm{ab}$ & $0.22 a b$ & $5.87 a b$ & $59.89 \mathrm{bc}$ & $32.10 \mathrm{bc}$ & $9.01 a$ & $2.88 \mathrm{bc}$ & $0.21 a$ & $5.93 a b$ \\
\hline & 80 & $58.5 b$ & $32.50 \mathrm{bc}$ & $9.10 \mathrm{a}$ & $2.53 a b$ & $0.21 a$ & $5.81 a$ & $57.90 \mathrm{~b}$ & $32.50 \mathrm{bc}$ & $9.60 a$ & 2.61ab & $0.23 a$ & $5.85 a$ \\
\hline & 100 & $54.70 a$ & $35.50 \mathrm{c}$ & $9.80 a$ & $2.28 a$ & $0.21 a$ & $5.69 a$ & $54.81 a$ & $35.46 c$ & $10.69 a$ & $2.41 a$ & $0.19 a$ & $5.82 \mathrm{a}$ \\
\hline & LSD & 7.15 & 6.02 & 5.33 & 0.66 & 0.16 & 0.33 & 5.51 & 4.2 & 4.79 & 0.28 & 0.04 & 0.27 \\
\hline
\end{tabular}

Means with the same letters within the same column are not significantly different $(P \leq 0.05$; Soil Textural Class = Sandy Clay Loam Key: OC = Soil organic carbon; $\mathrm{N}=$ Total Nitrogen 
between treatments (distance $\times$ season $\times$ piosphere) were not significant $(F=1.38, P=0.309)$.

Similarly, total nitrogen significantly decreased $(F=3.90$, $P=0.037)$ with piospheric distance. No significant difference was however observed in total nitrogen between piospheres $(F=0.74, P=0.503)$, seasons $(F=3.55, P=0.089)$, and the interactions between the treatments of distance $x$ season $\times$ piosphere $(F=0.73, P=0.663)$.

It was observed that grazing livestock spent more time near the piospheres. As such, defecation and urination by these animals could have enhanced nutrient deposition and accumulation leading to soil organic carbon and nitrogen augmentation. Stumpp et al. (2005) reported high dung deposits around the Mongolian piospheres. Smet and Ward (2006) and Shahriary et al. (2012) also reported high soil organic carbon and total nitrogen around the piospheres of South Africa and Iran, respectively. Anthony et al. (2015) also observed high total nitrogen near the piospheres of Karamoja, Uganda.

\section{Soil pH}

Soil pH significantly decreased $(F=12.69, P=0.001)$ with piospheric distance. No significant difference was however observed in soil $\mathrm{pH}$ between piospheres $(F=0.46, P=0.874)$, seasons $(F=0.01, P=1.000)$, and the interactions between the treatments of distance $\times$ season $\times$ piosphere $(F=0.01, P=1.000)$.

High compaction near the piospheres reduced infiltration which might have hampered nutrient leaching to the lower horizons of the soil profile. According to Beukes and Ellis (2003), sodium and calcium ions accumulate at the soil surface when leaching is hindered, leading to increased soil $\mathrm{pH}$. This could have been the possible reason for the significantly higher $(P \leq 0.05)$ soil $\mathrm{pH}$ observed near the piospheres. Al-Seekh et al. (2009) also observed high soil $\mathrm{pH}$ in high intensity grazing areas in the West Bank rangelands of Pakistan. Similarly, Smet and Ward (2006) and Anthony et al. (2015) reported high soil $\mathrm{pH}$ near the piospheres of South Africa and Karamoja, Uganda, respectively. Further, Shahriary et al. (2012) witnessed a decreasing trend in soil pH from Iranian piospheres.

\section{Conclusions}

The high soil compaction around the piospheres resulted in high soil bulk density and reduced soil porosity. Consequently, soil hydraulic conductivity was hampered, reducing soil moisture content. Bare grounds near the piospheres further exposed the soil to impact of raindrops, decreasing soil aggregate stability and making the soils vulnerable to erosion. This could have been the reason sand content was higher near the piospheres, because the fine clay and silt particles had been carried off by either water or wind. It is recommended that that grazing animals be placed under strict monitoring to reduce the amount of time spent around the piospheres and minimize soil compaction. Alternatively, the number of piospheres can be increased to reduce the number of animals drinking from each. Range reseeding should also be done to rehabilitate the areas that are already degraded.

\section{Acknowledgements}

This study was funded by the International Canopy of Conservation (I-CAN) and the African Conservation Centre (ACC) through the African Drylands Institute for Sustainability (ADIS) at the University of Nairobi. We also acknowledge Anyika, F, Muliro BA, and P Kimotho for their help in soil analysis. Special thanks to the management of Mopel Ranch, Kiserian for allowing us to conduct the research within their premises.

\section{Authors' contributions}

JS designed the study, collected the data, and participated in the data analysis; JS also drafted the manuscript write up and revised the manuscript. $\mathrm{KO}$ was part of the study design, data cleaning and analysis, and manuscript write up and revision. KG was part of the study design, data analysis and presentation, and manuscript editing. MJ was part of the research design and methodology, data analysis, and contributed to the results write up and manuscript editing. All authors read and approved the final manuscript.

\section{Competing interests}

The authors declare that they have no competing interests in this paper and the study as a whole.

\section{Publisher's Note}

Springer Nature remains neutral with regard to jurisdictional claims in published maps and institutional affiliations.

Received: 16 November 2016 Accepted: 11 April 2017

Published online: 05 May 2017

\section{References}

Alaoui A, Lipiec J, Gerke HH (2011) A review of the changes in the soil pore system due to soil deformation: A hydrodynamic perspective. Soil Tillage Res 115:1-15

Alphayo L (2015) Effects of holistic grazing management on soil physio-chemical properties and herbaceous vegetation production in Naibunga Conservancy, Laikipia County, Kenya. University of Nairobi, Doctoral dissertation

Al-Seekh SH, Mohammad AG, Amro YA (2009) Effect of grazing on soil properties at southern part of West Bank Rangeland. Hebron Univ Res J 4(1):35-53

Amiri ME, Fallahi E, Golchin A (2008) Influence of foliar and ground fertilization on yield, fruit quality, and soil, leaf, and fruit mineral nutrients in apple. J Plant Nutr 31(3):515-525

Anthony E, Bernard B, Henry MM, Paul N (2015) Piosphere Syndrome and Rangeland Degradation in Karamoja Sub-region, Uganda. Resourc Environ 5(3):73-89

Arnhold S, Otieno D, Onyango J, Koellner T, Huwe B, Tenhunen J (2015) Soil properties along a gradient from hillslopes to the savanna plains in the Lambwe Valley, Kenya. Soil Tillage Res 154:75-83

Azarnivand H, Farajollahi A, Bandak E, Pouzesh H (2010) Assessment of the effects of overgrazing on the soil physical characteristic and vegetation cover changes in rangelands of Hosainabad in Kurdistan province, Iran. J Rangeland Sci 1(2):95-102

Bekure, S (1991) Maasai herding: an analysis of the livestock production system of Maasai pastoralists in eastern Kajiado District, Kenya (Vol. 4). ILRI (aka ILCA and ILRAD).

Bell ALW (2010) Impacts of soil compaction by livestock on crop productivity-a modelling analysis. In: Proceedings of the 19th World Congress of Soil Science: Soil solutions for a changing world, Brisbane, Australia, Symposium 3.1. 2 Farm system and environment impacts. International Union of Soil Sciences (IUSS)., pp 117-120

Beukes PC, Ellis F (2003) Soil and vegetation changes across a Succulent Karoo grazing gradient. Afr J Range Forage Sci 20(1):11-19 
Brenner JM, Mulvaney CS (1982) Nitrogen total. In: Black CA (ed) Methods in Soil Analysis: Agronomy., pp 595-624

Brooks ML, Matchett JR (2006) Spatial and temporal patterns of wildfires in the Mojave Desert, 1980-2004. J Arid Environ 67:148-164

Buresh RJ, Austin ER, Craswell ET (1982) Analytical methods in15N research. Fertil Res 3(1):37-62

Chaichi MR, Saravi MM, Malekian ARASH (2005) Effects of livestock trampling on soil physical properties and vegetation cover (case study: Lar Rangeland, Iran). Int J Agric Biol 7:904-908

Cournane FC, McDowell RW, Condron LM (2010) Do aggregation, treading, and dung deposition affect phosphorus and suspended sediment losses in surface runoff? Soil Res 48(8):705-712

Day PR (1965) Particle fractionation and particle-size analysis. In: Methods of soil analysis. Part 1. Physical and mineralogical properties, including statistics of measurement and sampling, (methodsofsoilana)., pp 545-56

Flint AL, Flint LE (2002) Particle Density. In: Methods of Soil Analysis: Part 4 Physical Methods, (methodsofsoilan4)., pp 229-240

Gomez E, Ferreras L, Toresani S (2006) Soil bacterial functional diversity as influenced by organic amendment application. Bio Res Technol 97(13): 1484-1489

Han G, Hao X, Zhao M, Wang M, Ellert BH, Willms W, Wang M (2008) Effect of grazing intensity on carbon and nitrogen in soil and vegetation in a meadow steppe in Inner Mongolia. Agric Ecosyst Environ 125(1):21-32

Ingram LJ, Stahl PD, Schuman GE, Buyer JS, Vance GF, Ganjegunte GK, Derner JD (2008) Grazing impacts on soil carbon and microbial communities in a mixed-grass ecosystem. Soil Sci Soc Am J 72(4):939-948

Landman M, Schoeman DS, Hall-Martin AJ, Kerley GI (2012) Understanding longterm variations in an elephant piosphere effect to manage impacts. PLoS One 7(9):e45334

McKenzie, N, Jacquier, D, Isbell, R, Brown, K (2004) Australian soils and landscapes: an illustrated compendium. CSIRO publishing

McLean EO (1982) Soil pH and lime requirement. Methods of soil analysis. Part 2. Chemical and microbiological properties. Methodsofsoilan 2:199-224

Middleton, N, Thomas, D. (1997) World atlas of desertification Arnold, Hodder Headline, PLC.

Mohammed A (2000) Vegetation cover and productivity of the rangeland in the Southern part of West Bank. Bethlehem Univ J 19:75-87.27

Mugerwa S, Emmanuel Z (2014) Drivers of grassland ecosystems' deterioration in Uganda. Appl Sci Rep 2(3):103-111

Nelson DW, Sommers L (1982) Total carbon, organic carbon, and organic matter. Methods of soil analysis. Part 2. Chemical and microbiological properties. Methodsofsoilan 2:539-579

Ogutu JO, Owen-Smith N, Piepho HP, Said MY, Kifugo S, Reid RS, Andanje S (2013) Changing wildlife populations in Nairobi National Park and adjoining Athi-Kaputiei Plains: collapse of the migratory wildebeest. Open Conserv Biol J 7:11-26

Ombogo MO (2013) Impact of climate variability on pastoralism: forage dynamics and trends in cattle population in Kajiado County, Kenya. University of Nairobi), Doctoral dissertation

Pei, S, Fu, Wan, C (2008) Changes in soil properties and vegetation following exclosure and grazing in degraded Alxa desert steppe of Inner Mongolia, China. Agriculture, Ecosystem and Environment (in press)

Reynolds WD, Elrick DE (2002) Constant head soil core (tank) method. Methods Soil Anal Part 4:804-808

Schrama M, Heijning P, Bakker JP, van Wijnen HJ, Berg MP, Olff H (2013) Herbivore trampling as an alternative pathway for explaining differences in nitrogen mineralization in moist grasslands. Oecologia 172(1):231-243

Shahriary E, Palmer MW, Tongway DJ, Azarnivand H, Jafari M, Saravi MM (2012) Plant species composition and soil characteristics around Iranian piospheres. J Arid Environ 82:106-11

Smet M, Ward D (2006) Soil quality gradients around water-points under different management systems in a semi-arid savanna, South Africa. J Arid Environ 64(2):251-269

Stankovičová K, Novák J, Bajla J, Chlpík J (2008) Penetration resistance of soil on the year-long using mountain pasture by the cattle. J Cent Eur Agric 9(2): $311-316$

Sternberg T (2012) Piospheres and pastoralists: vegetation and degradation in steppe grasslands. Hum Ecol 40(6):811-820

Stumpp M, Wesche K, Retzer V, Miehe G (2005) Impact of grazing livestock and distance from water source on soil fertility in southern Mongolia. Mt Res Dev 25(3):244-251
Sun DS, Wesche K, Chen DD, Zhang SH, Wu GL, Du GZ, Comerford NB (2011) Grazing depresses soil carbon storage through changing plant biomass and composition in a Tibetan alpine meadow. Plant Soil Environ 57(6):271-278

Todd SW (2006) Gradients in vegetation cover, structure and species richness of Nama-Karoo shrublands in relation to distance from livestock watering points. J Appl Ecol 43(2):293-304

Wahome CN, Okemo PO, Nyamache AK (2014) Microbial quality and antibiotic resistant bacterial pathogens isolated from groundwater used by residents of Ongata Rongai, Kajiado North County, Kenya. Int J Biol Chem Sci 8(1):134-143

Wasonga, VO (2009) Linkages between land-use, land degradation and poverty in semi-arid rangelands of Kenya: the case of Baringo district. Doctoral dissertation, University of Nairobi, Department of agriculture.

Zhang S, Grip H, Lövdahl L (2006) Effect of soil compaction on hydraulic properties of two loess soils in China. Soil Tillage Res 90(1):117-125

\section{Submit your manuscript to a SpringerOpen ${ }^{\circ}$ journal and benefit from:}

- Convenient online submission

- Rigorous peer review

- Immediate publication on acceptance

- Open access: articles freely available online

- High visibility within the field

- Retaining the copyright to your article

Submit your next manuscript at springeropen.com 